\title{
USER ACCEPTANCE OF DATA INFORMED DECISION MAKING PORTALS: APPLICATION OF THE UTAUT MODEL AND LEADERSHIP STYLES
}

\author{
Jefri Marzal $^{1)}$, Rizqa Raaiqa Bintana ${ }^{2)}$, Pradita Eko Prasetyo Utomo ${ }^{3)}$ \\ 1), 2), 3) Universitas Jambi, Jambi, Indonesia \\ Correspondence Author: jefri.marzal@unja.ac.id
}

\begin{abstract}
In general, to make decisions in the discipline of information systems are divided into two, namely Decision Support System (DSS) and Data Informed Decision Making (DIDM). DIDM is a data-driven decision-making process taking into account previous experience, user research, and other important information. Many applications are categorized as data-informed for universities, one of which is a portal that contains data or information about various aspects of a university. There are not many known factors that influence leaders to use informed data as a tool for making decisions. This study applies the UTAUT (Unified Theory of Acceptance and Use of Technology) model by adding a leadership style variable as a moderating variable. Hypothesis testing using the bootstrapping technique in this study involved a number of samples $(N)$ of 300, testing for the two-tailed hypothesis, using a significance level of 5\%. Based on the test results revealed only facilitating conditions that affect use behavior. Meanwhile, the variables of performance expectancy, effort expectancy, and social influence have no effect on behavioral intention to use the application. In addition, it was also found that the moderator variable of leadership style did not affect the relationship between performance expectancy, effort expectancy, social influence, and facilitating conditions with the intention and actual use of leaders in data informed applications to make decisions.
\end{abstract}

Keywords: acceptance of use, data informed, decision-making, leadership style, UTAUT

\section{Introduction}

Decision making is the most important responsibility for all levels of leadership in a university. Decision making as a very important obligation of the leadership can be defined as obtaining and researching relevant information about managerial issues, for reasons of making the most appropriate choice among the available alternatives. An understanding of the decision-making process is very important for all levels of leadership, because an educational organization as a whole is a decision-making structure.

Although the intensity of decision-making may differ in several ways, there is always a desire to build the right decision in certain circumstances. So it seems very important that every university administrator makes provisions for decision making. Good decisions from all levels of leadership will be able to spur positive organizational performance (Alhawamdeh \& Alsmairat, 2019).

A transformation in the use of data for decision making in higher education has begun. In general, to make decisions in the discipline of information systems, it is divided into two, namely system-assisted decision making called the Decision Support System (DSS) and Data Informed Decision Making (DIDM). DSS pays attention to, maintains, and cultivates managerial decision making (Arnott \& Pervan, 2014). This system is intended to help middle and senior level managers build complex and strategic decisions in their day-to-day operations (Majchrzak \& Gasser, 2000). A DSS provides decisions based on algorithms derived from an understanding of the application domain. Decision making with DSS is rarely used by universities in most developing countries. Among the reasons are, the habit of developing countries in making decisions with the help of systems or applications has not yet been cultivated and the price for making applications is still considered quite expensive.

Meanwhile, DIDM is a data-driven decision-making process taking into account previous experience, user research, and other important information. DIDM as the process of organizing data resources, performing data analysis, and developing data insights to provide context and an evidence base for formulating organizational decisions (Webber \& Zheng, 2019). Thus, in addition to leaders being equipped with adequate data and excellent analysis, they also need to draw on their professional experience, political acumen, ethical practice, and strategic considerations in making decisions. Data cannot be very useful unless they can be analyzed in a timely manner and developed with contextualized meaning.

Many applications are categorized as data-informed for universities, one of which is a portal that contains data or information about various aspects of a university. In this study, the author took the UNJA Statistics portal in Figures with the domain https://dss.unja.ac.id. Briefly, this application contains information about students, lecturers, lecture achievements, university achievements, research and other lecturer activities. Information is displayed in numbers and graphs, and can be used for data-informed decision making. 
Several studies have revealed the effectiveness of computer systems in improving decisions. The quality of business intelligence systems can improve the quality of decisions (Darma, 2016). Data-informed to improve the quality of decisions made. However, there is not much research that reveals the factors that influence a leader to use data-informed applications in making a decision.

Many recent studies have shown that differences between individuals affect the acceptance and use of IT (Thatcher \& Perrewé, 2002). However, studies on the relationship between leadership style and technology acceptance have not been found. Leadership style is the difference in individual leadership styles can moderate the relationship between factors that influence a person's behavior to use information provider applications. The author develops the UTAUT (Unified Theory of Acceptance and Use of Technology) model by adding a leadership style variable as a moderating variable.

This study aims to examine the determinants of the leader's behavioral intention to use an information provider application by applying the UTAUT model as a guide. In addition, the moderating effect of leadership style on this relationship was also examined.

\section{Methods}

According to the UTAUT model, the acceptance rate of informed data applications can be influenced by many characteristics or factors such as performance expectations, business expectations, social influences, facilitating conditions, and behavioral intentions to use applications. In this study, researchers developed the UTAUT model by adding a leadership style variable as a moderating variable to the behavioral intention and use behavior variables to use technology, which can be seen in Figure 1.

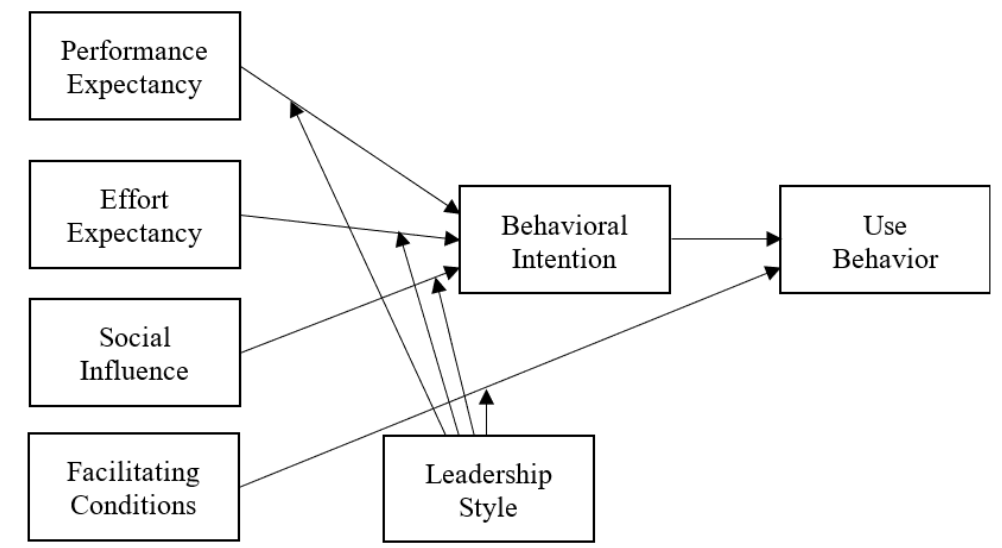

Fig. 1 Research model for acceptance of DIDM applications

Based on the above framework, the research hypothesis is formulated, namely:

1) Performance expectancy, defined as the extent to which an individual believes that using the system will help the individual to achieve gains in job performance.

H1: Performance expectancy have a positive effect on the behavioral intention of leaders to use DIDM applications.

2) Effort expectancy, defined as the level of ease associated with using the system.

$\mathrm{H} 2$ : Business expectations have a positive effect on the behavioral intention of leaders to use data provider applications.

3) Social influence, defined as the extent to which an individual perceives that important others believe that the individual should use the new system.

H3: Social influence has a positive effect on the behavioral intention of leaders to use data provider applications.

4) Facilitating conditions, the extent to which an individual believes that the organizational and technical infrastructure exists to support the use of the system is an indication of the existence or facilitating conditions.

H4: Facilitating conditions have a positive effect on the leadership's actual usage behavior of the data provider application.

5) Behavioral intentions

H5: The behavioral intention to use the data provider application has a significant positive effect on the leader's actual use behavior to make a decision.

6) Leadership style, several studies have been conducted to see the relationship between leadership style and the use of ICT in education. Among them is that there is a strong positive correlation between the transformation leadership style and the use of computers. 
H6: Leadership style moderates the relationship between (a) performance expectancy, (b) effort expectancy, (c) social influence, and (d) facilitating conditions, as well as behavioral intentions to use DIDM applications.

This study investigates how the UTAUT model can be applied to determine the acceptance of an informed data provider application that is used to help make decisions. The UTAUT model was chosen in this study because although it has been revised, it still maintains its completeness and high explanatory power. The UTAUT model identifies performance expectations, effort expectations, social influences, and facilitating conditions as direct determinants of behavioral intentions and usage behavior towards applications (Venkatesh \& Smith, User Acceptance of Information Technology: Toward A Unified View, 2003). In general, the main stages in this research are:

a) Identify Leadership Types

Duncan in his book entitled Organizational Behavior (Duncan, 1981), identifies six types of leadership, including Autocratic, Democratic, Delegative, Transformational, Transactional, and Situational. The characteristics of this type of leadership are used by researchers to identify the type of leadership that exists at Jambi University through distributing questionnaires to employees in each work unit. From the identification results, it will be known the type of leadership of each work unit leader.

b) Evaluation of PLS-SEM results

Evaluation of PLS-SEM results involves two stages of work. Phase 1 addresses examining the reflective measurement model (Stage 1.1), the formative measurement model (Stage 1.2), or both. Next, the researcher continued with Phase 2 of the evaluation of the structural model. In summary, Stage 1 examines the theory of measurement, while Stage 2 includes structural theory which involves testing the proposed hypotheses and discussing the relationships among latent variables (Sarstedt, Ringle, \& Hair, 2017).

\section{Results and Discussions}

To test the results of the study, the measurement model (outer model), structural model (inner model), and hypothesis testing were conducted.

a) Test results of the measurement model (outer model) and structural (inner model)

The measurement model is used to explain how the constructs and their indicators are measured and are reliable or valid and reliable by looking at convergent validity, discriminant validity, and construct reliability. While the evaluation of the structural model knows at the significance of the relationship between constructs or latent variables.

Table 1. PLS assessment criteria

\begin{tabular}{|c|c|}
\hline Criteria & Explanation \\
\hline \multicolumn{2}{|l|}{ Structural model evaluation } \\
\hline $\mathrm{R}^{2}$ for endogenous latent variable & $\begin{array}{l}\text { The results of } \mathrm{R}^{2} \text { of } 0.67,0.33 \text { and } 0.19 \text { for endogenous } \\
\text { variables in the structural model indicate that the model is } \\
\text { "good", "moderate", and "weak" }\end{array}$ \\
\hline \multicolumn{2}{|c|}{ Evaluation of reflective measurement model } \\
\hline Loading Factor & The value of loading factor $\geq 0.70$ \\
\hline Composite Reliability & $\begin{array}{l}\text { Composite reliability measure internal consistency and the } \\
\text { value should be greater then } 0.70\end{array}$ \\
\hline Average Variance Extracted & $\begin{array}{l}\text { The value of Average Variance Extracted (AVE) must be } \\
\text { greater then } 0.5\end{array}$ \\
\hline Discriminant validity & $\begin{array}{l}\text { The value of the square root and AVE must be greater than } \\
\text { the correlation value between latent variables }\end{array}$ \\
\hline Cross Loading & The value of Cross Loading $>0.5$ \\
\hline
\end{tabular}

Source: (Ghozali I. , 2012).

Table 2 shows that there are invalid indicators in this study, namely FC1, DELE, OTO, and TRANSAKS. These values are below 0.7 based on the PLS assessment criteria in Table 1, it is concluded that the variable indicator has a low level of validity. The AVE value on the Leadership Style variable is smaller than 0.5, so it is said that the construct is not convergently valid. This can also be seen from the number of construct indicators which have an outer loading value below 0.7 . 
Table 2. Construct validity test

\begin{tabular}{|c|c|c|c|c|}
\hline Variabel & Indikator & Loading Factor & Explanation & AVE \\
\hline \multirow{4}{*}{$\begin{array}{l}\text { Performance } \\
\text { Expectancy }(P E)\end{array}$} & PE1 & 0,879 & Valid & \multirow{4}{*}{0,808} \\
\hline & PE2 & 0,889 & Valid & \\
\hline & PE3 & 0,893 & Valid & \\
\hline & PE4 & 0,935 & Valid & \\
\hline \multirow{4}{*}{$\begin{array}{l}\text { Effort } \\
\text { Expectancy (EE) }\end{array}$} & EE1 & 0,944 & Valid & \multirow{4}{*}{0,876} \\
\hline & EE2 & 0,961 & Valid & \\
\hline & EE3 & 0,903 & Valid & \\
\hline & EE4 & 0,934 & Valid & \\
\hline \multirow{3}{*}{$\begin{array}{l}\text { Social Influence } \\
\text { (SI) }\end{array}$} & SI1 & 0,959 & Valid & \multirow{3}{*}{0,908} \\
\hline & SI2 & 0,945 & Valid & \\
\hline & SI3 & 0,955 & Valid & \\
\hline \multirow{4}{*}{$\begin{array}{l}\text { Facilitating } \\
\text { Conditions }(F C)\end{array}$} & $\mathrm{FC} 1$ & 0,574 & Invalid & \multirow{4}{*}{0,633} \\
\hline & $\mathrm{FC} 2$ & 0,929 & Valid & \\
\hline & FC3 & 0,821 & Valid & \\
\hline & FC4 & 0,816 & Valid & \\
\hline \multirow{3}{*}{$\begin{array}{l}\text { Behavioral } \\
\text { Intention (BI) }\end{array}$} & BI1 & 0,845 & Valid & \multirow{3}{*}{0,698} \\
\hline & BI2 & 0,851 & Valid & \\
\hline & BI3 & 0,809 & Valid & \\
\hline \multirow{2}{*}{$\begin{array}{l}\text { Use Behavior } \\
(U B)\end{array}$} & UB1 & 0,974 & Valid & \multirow{2}{*}{0,951} \\
\hline & UB2 & 0,976 & Valid & \\
\hline \multirow{6}{*}{$\begin{array}{l}\text { Leadership Style } \\
(L S)\end{array}$} & DELE & $-0,357$ & Invalid & \multirow{6}{*}{0,485} \\
\hline & DEMO & 0,831 & Valid & \\
\hline & OTO & 0,335 & Invalid & \\
\hline & SITUASI & 0,905 & Valid & \\
\hline & TRANFORM & 0,864 & Valid & \\
\hline & TRANSAKS & 0,642 & Invalid & \\
\hline
\end{tabular}

The construct reliability test was conducted to measure the accuracy, precision, and consistency of the instrument in measuring the construct. The reliability test is measured by looking at the composite reliability value where the value must be above 0.7. Based on the data in Table 3, it can be concluded that each construct used in this study is declared reliable (can be consistent in a series of measurements) and meets the requirements because the composite reliability value of each construct used in this study has a value above 0.7 .

Table 3. Construct reliability test

\begin{tabular}{lcc}
\hline \multicolumn{1}{c}{ Variabel } & Composite Reliability & Explanation \\
\hline Performance Expectancy & 0,944 & Reliable \\
Effort Expectancy & 0,966 & Reliable \\
Social Influence & 0,967 & Reliable \\
Facilitating Conditions & 0,870 & Reliable \\
Leadership Style & 0,771 & Reliable \\
Behavioral Intention & 0,874 & Reliable \\
Use Behavior & 0,975 & Reliable \\
\hline
\end{tabular}

Table 4 shows that the behavioral intention variable has an R-Square value of 0.442 and use behavior of 0.310 . This shows that the behavioral intention variable is influenced by the performance expectancy, effort expectancy, social influence, and facilitating condition variables by $44.2 \%$ moderated by the leadership style variable and it is concluded that the R-Square value belongs to the "Moderate" or "Medium" model. While the use behavior variable is influenced by the facilitating condition and behavioral intention variables by $31 \%$ moderated by the leadership style variable and it is concluded that the R-Square value is classified as a "weak" model. 
Table 4. R-Square value

\begin{tabular}{ccc}
\hline Variabel & $R$-Square & Explanation \\
\hline Behavioral Intention & 0,442 & moderate \\
Use Behavior & 0,310 & weak \\
\hline
\end{tabular}

b) Hypothesis testing

Hypothesis testing was conducted to answer the problems in this study, namely the effect of certain exogenous variables on endogenous variables. Hypothesis testing is done by using the bootstrapping analysis on the path coefficients, namely by comparing the t-statistics with the t-table.

Hypothesis testing using the bootstrapping technique in this study involved a number of samples $(\mathrm{N})$ of 300 , testing for the two-way hypothesis (two tailed), using a significance level of 5\% or 0.05 . So that the t-table value used for this test is 1.96 . The formulation of the hypothesis is accepted if the value of t-statistic $>\mathrm{t}$-table. On the other hand, if the value of $\mathrm{t}$-statistic $<\mathrm{t}$-table, then the hypothesis is rejected.

Table 5. Hypothesis testing results

\begin{tabular}{lccc}
\hline & T-Table & T-Statistics & Explanation \\
\hline $\mathrm{H} 1: \mathrm{PE} \rightarrow$ BI & 1,96 & 1,311 & Rejected \\
$\mathrm{H} 2: \mathrm{EE} \rightarrow$ BI & 1,96 & 0,917 & Rejected \\
$\mathrm{H} 3: \mathrm{SI} \rightarrow \mathrm{BI}$ & 1,96 & 0,172 & Rejected \\
$\mathrm{H} 4: \mathrm{FC} \rightarrow \mathrm{UB}$ & 1,96 & 2,548 & Accepted \\
$\mathrm{H} 5: \mathrm{BI} \rightarrow \mathrm{UB}$ & 1,96 & 0,962 & Rejected \\
$\mathrm{H} 6: \mathrm{LS} \rightarrow \mathrm{BI}$ & 1,96 & 0,430 & Rejected \\
$\mathrm{H} 7: \mathrm{LS} \rightarrow$ UB & 1,96 & 0,169 & Rejected \\
$\mathrm{H} 8:$ Moderating LS PE & 1,96 & 0,046 & Rejected \\
$\rightarrow$ BI & & & \\
$\mathrm{H} 9:$ Moderating LS EE & 1,96 & 0,010 & Rejected \\
$\rightarrow$ BI & 1,96 & 0,217 & Rejected \\
$\mathrm{H} 10:$ Moderating LS SI & & & \\
$\rightarrow$ BI & 1,96 & 0,837 & Rejected \\
H11: Moderating LS & & & \\
FC $\rightarrow$ UB & & & \\
\hline
\end{tabular}

Based on Table 5, it can be seen that performance expectancy, effort expectations, and social influences have no effect on the intention to use an informed data provider application. The intention to use the application does not affect the actual use of the application. In this study, it was revealed that only the condition of the facility variable affected the actual use of the application. This finding is very logical for universities whose leaders are familiar with ICT, that as long as computer equipment and internet access are available, it will influence them to use DIDM applications. They do not care about the appearance of a good application, easy to use, or being influenced by other parties to use the application. This is reinforced by (Ambarwati, Harja, \& Thamrin, 2020) who state that the availability of internet access and mobile devices greatly influences the desire to use online learning technology.

This study also revealed that leadership style does not determines the relationship between performance expectancy, effort expectancy, and social influence with the intention to use the application. The leadership style has no effect on the relationship between facility conditions and actual application usage. Based on these findings, it can be said that the difference in leadership style does not affect the relationship between the main variables in the UTAUT model.

\section{References}

Alhawamdeh, H. M., \& Alsmairat, M. A. (2019). Strategic Decision Making and Organization Performance: A Literature Review. International Review of Management and Marketing, 95-99.

Ambarwati, R., Harja, Y. D., \& Thamrin, S. (2020). The Role of Facilitating Conditions and User Habits: A Case of Indonesian Online Learning Platform*. Journal of Asian Finance, Economics and Business, 481-489.

Arnott, D., \& Pervan, G. (2014). A Critical Analysis of Decision Support Systems Research Revisited: The Rise of Design Science. Journal of Information Technology, 269-293.

Darma, J. (2016). The Effect of Quality of Business Intelligence System on Quality of Decision Making (Survey on Financial Institutions in Medan City-North Sumatera). European Journal of Accounting, Auditing and Finance Research, 49-56.

Duncan, W. (1981). Organizational behavior (Vol. 2). Boston: Houghton Mifflin.

Ghozali, I. (2012). Structural Equation Modeling Metode Alternatif dengan Partial Least Square. Semarang: Badan Penerbit Universitas Diponegoro.

Majchrzak, A., \& Gasser, L. (2000). TOP-MODELER@: Supporting Complex Strategic and Operational Decisionmaking. Information, Knowledge, Systems Management, 95-110.

Sarstedt, M., Ringle, C., \& Hair, J. (2017). Partial Least Squares Structural Equation Modeling. In Handbook of Market Research. Springer. 
Thatcher, J. B., \& Perrewé, P. L. (2002). An Empirical Examination of Individual Traits as Antecedents to Computer Anxiety and Computer Self-Efficacy. MIS Quarterly, 381-396.

Venkatesh, V., \& Smith, R. (2003). User Acceptance of Information Technology: Toward A Unified View. MIS Quarterly, 425478.

Webber, K. L., \& Zheng, H. Y. (2019). Analytics and the Imperatives for Data-Informed Decision Making in Higher Education. In Data Analytics In Higher Education (pp. 1-33). Baltimore: Johns Hopkins University Press. 